\title{
RESULTS OF WHEAT WINTER WHEAT BREEDING FOR RESISTANCE TO THE MAIN PATHOGENS OF DISEASES IN THE MYRONIVKA INSTITUTE OF WHEAT
}

\author{
H. M. Kovalyshyna, Yu. M. Dmytrenko, O. A. Demydov, T. I. Mukha, \\ L. A. Murashko
}

\begin{abstract}
For the period 2016-2018, evaluated new winter wheat varieties for resistance to six diseases on artificial infectious backgrounds of their pathogens. The lowest damage to wheat plants by leaf rust was found on the varieties Beregynia Myronivska (5.0 \%), Gospodynia Myronivska (6.7 \%), Trydivnytsia Myronivska (7.3 \%); powdery mildew - MIP Valensiia, MIP Vyshyvanka (8.7\%), Beregynya Myronivska (9.3\%); septoriosis - Gorlytsia Myronivska and Beregynya Myronivska (8.3\%); root rot - MIP Kniazhna (13.7\%), Trydivnytsia Myronivska (14.7\%). Defeat of the causative agents of the fusarium at a level of $2 \%$ was marked on the Bereginya Myronivska variety. Selected varieties with resistance to two, three and four diseases: Gorlitsa Myronivska, Trydivnytsia Myronivska, MIP Kniazhna, MIP Vishivanka and Bereginya Myronivska. Newly created varieties significantly exceeded the indicators of disease resistance of varieties that were created in the previous period.

Keywords: triticum aestivum L., varieties, pathogen, resistance, disease, artificial infectious background
\end{abstract}

\section{ВИХІД ВИСОКОЯКІСНОГО НАСІННЯ КУКУРУДЗИ В ЗАЛЕЖНОСТІ ВІД ГУСТОТИ СТОЯННЯ РОСЛИН}

\author{
В. В. БАГАТЧЕНКО, аспірант* \\ E-mail:volodimirbagatchenko@ukr.net
}

\begin{abstract}
Анотація. Вивчаються питання оптимальної густоти стояння рослин батьківських форм кукурудзи як самозапилених ліній, так $i$ простих міжлінійних гібридів на ділянках гібридизації, які впливають на показники врожайності та їх насіннєву продуктивність.

Дослідження проводилися протягом 2014-2017 рр. у Правобережному Лісостепу України в ТОВ «Агрофрірма «Колос» Сквирського району, Київської області. Польові досліди включали варіанти з вивчення ефективності густоти стояння рослин батьківських форм кукурудзи: прості гібриди Ріст CВ, Рушник CB, Річка C (75, 85 i 95 тис / га), самозапилені лінії УР 9 зС, УР $331 \mathrm{CB}, \mathrm{YP} 12$ зC (85, 95 i $105 \mathrm{muc} /$ 2a).
\end{abstract}

В. Л. Жемойда

сільськогосподарських наук, доцент (CВ. В. БАГАТЧЕНКО, 2018 
Відзначається, що на формування врожаю, вологості зерна, маси 1000 зерен та показників виходу кондиційного насіння впливають густота стояння рослин, морфологічні ознаки батьківських форм та метеоумови, які складаються впродовж вегетаційного періоду.

Встановлено, що рекомендовані густоти стояння рослин сприяють утворенню вищої урожайності, низької збиральної вологості та підвищеному виходу кондиційного насіння.

Ключові слова: кукурудза, густота стояння рослин, батьківські форми, самозапилені лінії, еібриди, насіннєва продуктивність, вологість насіння, маса 1000 зерен, вихід кондиційного насіння, кліматичні умови

Актуальність. У світі спостерігається тенденція до збільшення виробництва зерна кукурудзи. За останніх 16 років обсяг виробництва зріс майже вдвічі - з 600 до1100 млн тон [1]. На даний час в Україні кукурудза вирощується на площі 4,3 млн га і займає третє місце за площею посівів. В цілому потенційні можливості гібридів кукурудзи реалізуються не повністю, а отже зростає необхідність в покращенні наявних технологій для впровадження нових гібридів кукурудзи, занесених до Реєстру сортів рослин України [2], із більш високим ефектом гетерозису і потенціалом урожайності, що дасть змогу без додаткових затрат значно збільшити виробництво зерна.

У комплексі агротехнічних заходів вирощування кукурудзи, від яких залежить урожай та його якість, важливе місце посідає густота стояння рослин.

Більш високі врожаї можливо отримати за рахунок високої індивідуальної продуктивності та гранично допустимої щільності стеблестою в конкретній зоні вирощування [3].

На перших етапах росту й розвитку, коли кукурудза формує слабо розвинену кореневу систему та листкову поверхню, рослини не реагують на загущення. Однак, настає момент, коли ріст одних рослин починає ускладнювати онтогенетичні процеси інших, що призводить до посилення конкуренції за фрактори життя, зниження життєздатності й продуктивності рослин $[4,5]$. В результаті міжрослинного ущільнення посилюється їхня конкуренція за фактори життя, насамперед, за воду, світло і мінеральні елементи, що позначається на індивідуальній продуктивності рослин.

Густота рослин - один із головних фракторів, який визначає ефрективність використання родючості, температурного та водного режимів ґрунту, сонячної енергії та інших складових життєдіяльності агроценозу [6]. В той же час, єдиної думки відносно оптимальної густоти стояння рослин немає. Циков В. С. (2003) відмічає, що цей показник залежить як від кліматичних умов, так і від генотипу гібрида і в умовах Правобережного Лісостепу України і коливається від 55 до 95 тис / га [3].

Витримувати рекомендовану густоту стояння кукурудзи дуже важливо тому, що відхилення від оптимальних параметрів як в сторону загущення, так і в сторону зрідження може призвести до значного недобору, а інколи і до повної втрати врожаю [7]. 
В умовах достатнього зволоження, внаслідок високого потенціалу продуктивності кукурудзи, максимального використання біокліматичного потенціалу регіону, родючості ґрунтів, мінеральних добрив і біологічних можливостей самозапилених ліній є можливість значно збільшити щільність посіву до 75-105 тис / га, що дасть змогу підвищити урожайність на 15-20 \% [7]. Але, слід пам'ятати, що за відповідних умов навколишнього середовища асиміляційний апарат кукурудзи здатний засвоїти максимальну кількість сонячної радіації, що позитивно позначається на поглинанні поживних речовин. В розріджених посівах за оптимального розподілу ФАР між ярусами листків інтенсивність фотосинтезу посилюється і показники чистої його продуктивності підвищуються, внаслідок чого накопичення сирої та абсолютно сухої речовини відбувається прискореними темпами.

Отже, вирішення питання формування продуктивності кукурудзи через оптимізацію густоти стояння рослин має теоретичне та практичне значення і $€$ достатньо актуальним, особливо для батьківських фрорм на ділянках гібридизації.

Метою досліджень було встановлення оптимальної густоти стояння рослин батьківських форм кукурудзи різних груп стиглості в умовах Київщини для підвищення їх насіннєвої продуктивності.

Предмет дослідження - ранньостиглий гібрид Ріст СВ, середньоранній - Річка С, середньостиглий -Рушник СВ та самозапилені лінії: ранньостигла - УР 9 зС, середньорання - УР 331 СВ, та середньостигла - УР 123С. Польові досліди включали варіанти 3 вивчення ефективності густоти стояння рослин батьківських фрорм кукурудзи (густота стояння становила: прості гібриди (75, 85 і 95 тис / га), для самозапилених ліній (85, 95 і 105 тис/га)). Повторення триразове. Розміщення ділянок систематичне. Всі основні технологічні заходи проводили згідно з зональними рекомендаціями, крім досліджуваних факторів. Клімат в зоні досліджень - помірно-континентальний з великими річними та добовими коливаннями температур.

Матеріали і методи проведення досліджень. Дослідження 3 оптимізації густоти стояння рослин проводили протягом 2014-2017 р.р. у Правобережному Лісостепу України в ТОВ «Агрофрірма «Колос» Сквирського району, Київської області. Ґрунт дослідного поля - чорнозем типовий середньогумусний крупнопилувато-середньосуглинковий на лесі. Вміст гумусу - 4,6 - 4,8 \% (за Тюріним), легкогідролізованого азоту - 14,4 мг / 100 г ґрунту, рухомого фоссрору - 9,6, обмінного калію - 15,2 мг / 100 г ґрунту. Об'ємна маса ґрунту в рівноважному стані - 1,24 г/ см ${ }^{3}$, гідролітична кислотність - 1,14 мг-екв/100 г ґрунту, $\mathrm{pH}$ сольова - 6,4. Ґрунти характеризуються середнім рівнем забезпечення поживних речовин.

За результатами досліджень відзначається, що густота стояння рослин суттєво впливає на формування індивідуальної продуктивності батьківських форм (гібридів) кукурудзи (табл. 1). Встановлено, що найвищі значення показника маси 1000 зерен всі батьківські форми сформували за густоти стеблостою 75 тис / га. Збільшення густоти стояння призвело до зменшення маси 1000 зерен. Аналіз отриманих результатів свідчить про існування зв'язку 
не тільки між вологістю зерна і густотою сівби, але й морфологічними ознаками гібридів кукурудзи. Відзначено, що при збільшенні густоти сівби вологість зерна кукурудзи закономірно підвищувалась. Найнижчий відсоток вологості мало зерно за сівби з густотою 75 тис / га, а найбільш вологим воно було за густоти 95 тис / га.

1. Елементи урожайності материнських форм (гібридів) кукурудзи в залежності від густоти стояння рослин (середне за 2014-2017 р.р.)

\begin{tabular}{|c|c|c|c|c|c|c|c|}
\hline \multirow{2}{*}{ 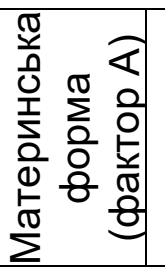 } & \multirow{2}{*}{$\begin{array}{c}\text { Густота } \\
\text { стояння } \\
\text { рослин, тис/ } \\
\text { га } \\
\text { (фрактор В) } \\
\end{array}$} & \multirow{2}{*}{$\begin{array}{c}\text { Ma- } \\
\text { ca } \\
1000 \\
\text { 3epe } \\
\mathrm{H}, \mathrm{r} \\
\end{array}$} & \multirow[t]{2}{*}{$\begin{array}{l}\text { Воло- } \\
\text { гість, } \\
\%\end{array}$} & \multirow[t]{2}{*}{$\begin{array}{c}\text { Вихід } \\
\text { зерна } \\
\text {,\% }\end{array}$} & \multirow{2}{*}{$\begin{array}{c}\text { Урожай- } \\
\text { ність зерна } \\
\text { за } 14 \text { \% } \\
\text { вологи, ц/ га }\end{array}$} & \multicolumn{2}{|c|}{$\begin{array}{c}\text { Вихід } \\
\text { кондиційного } \\
\text { насіння }\end{array}$} \\
\hline & & & & & & $\%$ & ц/га \\
\hline \multirow{3}{*}{$\begin{array}{l}0 \\
0 \\
\frac{b}{a}\end{array}$} & 75 & $\begin{array}{c}291 \\
4\end{array}$ & 14,8 & 83,9 & 90,3 & 95,1 & 85,9 \\
\hline & 85 & $\begin{array}{c}253 \\
3\end{array}$ & 15,6 & 83,5 & 83,0 & 94,7 & 78,6 \\
\hline & 95 & $\begin{array}{c}252 \\
7\end{array}$ & 15,8 & 83,9 & 91,3 & 92,3 & 84,3 \\
\hline \multirow{3}{*}{ 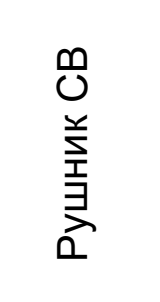 } & 75 & $\begin{array}{c}343 \\
5\end{array}$ & 18,2 & 81,8 & 78,9 & 97,6 & 77,0 \\
\hline & 85 & $\begin{array}{c}290 \\
3\end{array}$ & 18,7 & 81,3 & 76,6 & 96,3 & 73,8 \\
\hline & 95 & $\begin{array}{c}267 \\
9\end{array}$ & 19,6 & 81,6 & 73,4 & 94,2 & 69,1 \\
\hline \multirow{3}{*}{ 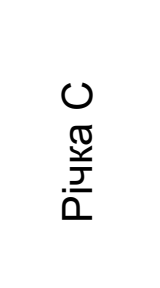 } & 75 & $\begin{array}{c}310 \\
3\end{array}$ & 17,3 & 82,8 & 76,9 & 95,7 & 73,6 \\
\hline & 85 & $\begin{array}{c}303, \\
1\end{array}$ & 17,5 & 82,9 & 81,8 & 93,7 & 76,6 \\
\hline & 95 & $\begin{array}{c}249 \\
8\end{array}$ & 17,7 & 80,8 & 76,3 & 93,1 & 71,0 \\
\hline $\begin{array}{c}\text { HIPAB } \\
05\end{array}$ & & 56,3 & 2,09 & 2,49 & 4,69 & & \\
\hline HIPA 05 & & 32,5 & 1,2 & 1,43 & 2,7 & & \\
\hline HIPB 05 & & 32,5 & 1,2 & 1,43 & 2,7 & & \\
\hline
\end{tabular}

Дані аналізу урожаю зерна кукурудзи показали, що на його формування впливали: густоти стояння рослин, морфологічні ознаки, а також метеорологічні умови впродовж вегетаційного періоду. У середньому, за роки досліджень (2014-2017 р.p.), ранньостиглий гібрид Ріст СВ сформував найвищу урожайність зерна 91,3 ц/ га при густоті 95 тис/ га, проте вихід кондиційного насіння був вищий за густоти 75 тис / га і склав 95,1\%, що становить 85,9 ц / га. Середньостиглий гібрид Рушник СВ сфрормував найвищу урожайність та вихід кондиційного насіння за густоти 75 тис / га, що становить 77,0 ц / га. Середньоранній гібрид Річка С найвищий вихід кондиційного насіння сформував за густоти 85 тис / га, що склало 76,6 ц / га.

Аналізуючи вплив густоти стояння при формуванні насіннєвого матеріалу самозапиленими лініями (табл. 2) можна зробити наступні 
висновки: що найвищі значення показника маси 1000 зерен було сформовано за густоти 85 тис/га. Збільшення густоти призвело до зменшення маси 1000 зерен. Відзначено, що при збільшенні густоти стояння вологість зерна кукурудзи більшості ліній підвищувалась. Найнижчу вологість мало зерно при густоті 85 тис/га, а найбільш вологим воно було за густоти 105 тис / га.

2. Варіювання елементів урожайності самозапилених ліній кукурудзи В залежності від густоти стояння рослин(середнє за 2014-2017 р.p.)

\begin{tabular}{|c|c|c|c|c|c|c|c|}
\hline \multirow{2}{*}{ 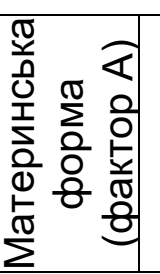 } & \multirow{2}{*}{$\begin{array}{c}\text { Густота } \\
\text { стояння } \\
\text { рослин, } \\
\text { тис / га } \\
\text { (фактор В) }\end{array}$} & \multirow{2}{*}{$\begin{array}{c}\text { Ma- } \\
\text { ca } \\
1000 \\
\text { 3epe } \\
\mathrm{H}, \mathrm{r}\end{array}$} & \multirow[t]{2}{*}{$\begin{array}{l}\text { Воло- } \\
\text { гість, } \\
\%\end{array}$} & \multirow[t]{2}{*}{$\begin{array}{c}\text { Вихід } \\
\text { зерна } \\
\text {, \% }\end{array}$} & \multirow{2}{*}{$\begin{array}{c}\text { Урожайніст } \\
\text { ь зерна за } \\
14 \text { \% } \\
\text { вологи, } \\
\text { ц / га }\end{array}$} & \multicolumn{2}{|c|}{$\begin{array}{c}\text { Вихід } \\
\text { кондиційного } \\
\text { насіння }\end{array}$} \\
\hline & & & & & & $\%$ & ц/га \\
\hline \multirow{3}{*}{$\begin{array}{l}0 \\
0 \\
0 \\
\lambda\end{array}$} & 85 & $\begin{array}{c}214, \\
0\end{array}$ & 15,3 & 80,3 & 40,7 & 95,2 & 38,7 \\
\hline & 95 & $\begin{array}{c}198, \\
7\end{array}$ & 17,5 & 80,3 & 37,3 & 91,5 & 34,1 \\
\hline & 105 & $\begin{array}{c}185, \\
3\end{array}$ & 16,1 & 79,4 & 38,1 & 85,2 & 32,5 \\
\hline \multirow{3}{*}{$\begin{array}{l}\infty \\
0 \\
\bar{m} \\
\stackrel{\infty}{\lambda}\end{array}$} & 85 & $\begin{array}{c}273 \\
0\end{array}$ & 21,0 & 82,7 & 44,4 & 96,3 & 42,8 \\
\hline & 95 & $\begin{array}{c}256 \\
7\end{array}$ & 19,2 & 83,5 & 47,5 & 92,4 & 43,9 \\
\hline & 105 & $\begin{array}{c}245, \\
3\end{array}$ & 20,1 & 83,3 & 46,7 & 90,2 & 42,1 \\
\hline \multirow{3}{*}{ 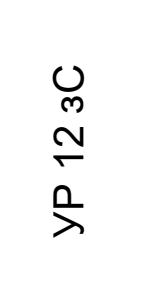 } & 85 & $\begin{array}{c}333, \\
1\end{array}$ & 24,4 & 78,1 & 47,3 & 94,9 & 44,9 \\
\hline & 95 & $\begin{array}{c}266 \\
4\end{array}$ & 22,9 & 78,1 & 45,9 & 92,4 & 42,4 \\
\hline & 105 & $\begin{array}{c}233 \\
8\end{array}$ & 25,5 & 79,9 & 43,1 & 90,2 & 38,9 \\
\hline $\begin{array}{l}\text { HIPAB } \\
05\end{array}$ & & 48 & 4,48 & 3,92 & 6,7 & & \\
\hline $\begin{array}{l}H I P A \\
H\end{array}$ & & 27,7 & 2,59 & 2,27 & 3,9 & & \\
\hline$H U P B 05$ & & 27,7 & 2,59 & 2,27 & 3,9 & & \\
\hline
\end{tabular}

Самозапилені лінії, зокрема, ранньостигла УР 9 зС та середньостигла УР 12 зС сформували найвищу урожайність кондиційного насіння при густоті 85 тис / га - 38,7 та 44,9 ц / га відповідно, а середньорання УР 331 СВ при густоті 95 тис/га. Усі досліджувані батьківські фрорми кукурудзи при збільшенні густоти стояння посівів формували більш дрібне та щупле зерно, що призвело до зниження виходу кондиційного насіння.

За результатами досліджень, найбільш оптимальною густотою стояння, при якій сформувався найвищий вихід кондиційного насіння, для гібридів Ріст СВ $(85,9$ ц/га) та Рушник (77,0 ц/га) відповідно, стала густота 75 тис/га; для гібрида Річка C (76,6 ц/га), та самозапилених 
ліній УР 9 зС (38,7 ц/га) та УР 12 зС (44,9 ц/га) - 85 тис/га; а для самозапиленої лінії УР 331 СВ (43,9 ц / га) - 95 тис / га.

Висновки і перспективи. У результаті проведених досліджень встановлено:

- оптимальною густою стояння, яка дає можливість отримати найвищу урожайність кондиційного насіння для гібридів Ріст СВ та Рушник, є густота 75 тис / га;

85 тис / га;

- для гібрида Річка С, самозапилених ліній УР 9 зС та УР 12 з С -

- для самозапиленої лінії УР 331 СВ - 95 тис / га;

Для отримання високих урожаїв насіння кукурудзи вищевказані гібриди та самозапилені лінії доцільно вирощувати за вказаною рекомендованою густотою стояння.

\section{References}

1. Baker tilly «Vyrobnytstvo kukurudzy v Ukraini: zrostannia vymahaie rozvytku» (2017) [Corn production in Ukraine: growth requires development] [in Ukrainian]. Available at : http://www.bakertilly.ua/news/id1294

2. Derzhavnyi reiestr sortiv roslyn prydatnykh do poshyrennia $v$ Ukraini (2016-2017 rr.) .) [State register of plant varieties suitable for distribution in Ukraine (2016-2017 gg.)] [in Ukrainian]

3. Tsykov, V. S. (2003). Kukuruza: tekhnolohyia, hybrydi, semena. [Corn: technology, hybrids, seeds]. Dnepropetrovsk: Yz-vo Zoria, 296.

4. Veretenykov, H. V. (1996). Hustota stoianyia rastenyi y semennaia produktyvnost rodytelskykh form. [Density of plant standing and seed productivity of parental forms]. Kukuruza y sorho, 4. 15-16. [in Russian]

5. Yakunin, O. P. (2011). Volohozabezpechenist ta vrozhainist hibrydiv kukurudzy kharchovoi zalezhno vid hustoty stoiannia roslyn. [Moisture and productivity of maize hybrids of food depending on the density of plants standing] Biuleten Instytutu silskoho hospodarstva stepovoi zony, 1, 42-46. [in Ukrainian]

6. Kosarskyi, V. Yu. (2010). Vplyv hustoty roslyn na vrozhainist zerna kukurudzy. [Influence of plant density on grain yield of corn]. Ahronom, 3, 70-72 [in Ukrainian]

7. Tarasov, O. V. (1974). Kukurudza v Stepu Ukrainy. [Corn in the Steppe of Ukraine]. Donetsk: Donbas, 124 [in Ukrainian]

8. Lavrynenko, Yu. O., Vozhehova, R. A. (2011). Kukurudza na zroshuvanykh zemliakh pivdnia Ukrainy: monohrafiia. [Corn on irrigated lands of southern Ukraine]. Kherson: Ailant, 468. [in Ukrainian]

\section{ВЫХОД ВЫСОКОКАЧЕСТВЕННЫХ СЕМЯН КУКУРУЗЫ В ЗАВИСИМОСТИ ОТ ГУСТОТЫ СТОЯНИЯ РАСТЕНИЙ}

\section{В. В. Багатченко}

Аннотация. Изучаются вопросы оптимальной густоты стояния растений родительских форм кукурузы как самоопылённых линий, так и простых межлинейных гибридов на участках гибридизации, влияющих на показатели урожайности и их семенную продуктивность. 
Исследования проводились в течение 2014-2017 ге. в Правобережной Лесостепи Украины в ООО "Агрофирма" Колос» Сквирского района, Киевской области. Полевые опыты включали варианты по изучению эфрфекттивности густоты стояния растений родительских фрорм кукурузы: простые гибриды Рист СВ, Рушник CB, Ричка C (75, 85 и 95 тыс / га), самоопыленные линии УР 9 зС, УР 331 СВ, УР 12 зС ( 85, 95 и 105 mыс / га).

Отмечается, что на формирование урожая, влажность зерна, массу 1000 семян и показатели выхода кондиционных семян влияют густота стояния растений, морфоологические признаки родительских форм и метеоусловия, которые складываются на протяжении вегетационного периода.

Установлено, что рекомендуемые густоты стояния растений способствуют образованию высокой урожайности, низшей уборочной влажности и высокому выходу кондиционных семян.

Ключевые слова: кукуруза, густота стояния растений, родительские формы, самоопылённые линии, гибриды, семенная продуктивность, влажность семян, масса 1000 семян, выход кондиционных семян, климатические условия

\section{OUTPUT OF A HIGH-QUALIFIED SEED SCREW \\ IN DEPENDENCE FROM THE STATUS OF POPULATION OF PLANTS}

\section{V. Bagatchenko}

Abstract. Studied the question of the optimal density of standing plants parent forms of corn, as the self-pollinated lines and simple interline hybrids in areas that affect hybridization yields and their seed productivity.

The research was conducted during 2014-2017 in the Right-bank Forest-steppe of Ukraine in the LLC "Agrofirma Kolos" of the Skvyra district of the Kyiv region. Field experiments included options for studying the effectiveness of the plant density of parental forms of corn: simple hybrids, Richka SV, Rushnik SV, River C (75, 85 and 95 thousand / ha), self-pollinated lines UR 9 zS, UR 331 SV, UR 12 zS 85, 95 and 105 thousand hectares).

It is marked, that the formation of crop, moisture, the mass of 1000 grains and the parameters of the release of conditioned seeds are influenced by: the density of plant standing, morphological signs of parental forms and meteorological conditions that are formed during the vegetative period.

It has been established that the recommended plant densities contribute to the formation of higher yields, low harvesting moisture and increased yield of conditioned seeds.

Keywords: corn, sowing norms, parental forms, self-pollinated lines, hybrids, seed productivity, seed moisture, weight of 1000 grains, yield of conditioned seeds, climatic conditions 